\title{
Endoglin (CD105) expression in ovarian serous carcinoma effusions is related to chemotherapy status
}

\author{
Annika J. Bock • Helene Tuft Stavnes • Janne Kærn • \\ Aasmund Berner • Anne Cathrine Staff • Ben Davidson
}

Received: 7 November 2010 / Accepted: 10 January 2011 / Published online: 26 February 2011

(C) The Author(s) 2011. This article is published with open access at Springerlink.com

\begin{abstract}
Endoglin (CD105), a cell surface co-receptor for transforming growth factor- $\beta$, is expressed in proliferating endothelial cells, as well as in cancer cells. We studied endoglin expression and its clinical relevance in effusions, primary tumors, and solid metastatic lesions from women with advanced-stage ovarian serous carcinoma. Endoglin expression was analyzed by immunohistochemistry in effusions ( $n=211 ; 174$ peritoneal, 37 pleural). Cellular endoglin staining was analyzed for association with the concentration of soluble endoglin (previously determined by ELISA) in 95 corresponding effusions and analyzed for correlation with clinicopathologic parameters, including survival. Endoglin expression was additionally studied in
\end{abstract}

A. J. Bock $\cdot$ H. Tuft Stavnes $\cdot$ A. Berner $\cdot$ B. Davidson

Department of Pathology, Oslo University Hospital,

Norwegian Radium Hospital,

0424 Oslo, Norway

\section{A. J. Bock $\cdot$ A. C. Staff}

Department of Gynecology, Oslo University Hospital,

Ulleval,

0424 Oslo, Norway

\section{J. Kærn}

Department of Gynecologic Oncology, Oslo University Hospital, Norwegian Radium Hospital,

0424 Oslo, Norway

\author{
A. Berner $\cdot$ A. C. Staff $\cdot$ B. Davidson \\ Faculty of Medicine, University of Oslo, \\ 0316 Oslo, Norway \\ B. Davidson $(\square)$ \\ Division of Pathology, Oslo University Hospital, \\ Norwegian Radium Hospital, \\ Montebello, \\ 0310 Oslo, Norway \\ e-mail: bend@medisin.uio.no
}

34 patient-matched primary tumors and solid metastases. Carcinoma and mesothelial cells expressed endoglin in 95/211 (45\%) and 133/211 (63\%) effusions, respectively. Carcinoma cell endoglin expression was more frequent in effusions from patients aged $\leq 60$ years $(p=0.048)$ and in post- compared to prechemotherapy effusions $(p=0.014)$, whereas mesothelial cell endoglin expression was higher in prechemotherapy effusions $(p=0.021)$. No association was found between cellular endoglin expression and its soluble effusion concentration. Endoglin was expressed in $17 / 34(50 \%)$ primary tumors and 19/34 (56\%) metastases, with significantly higher percentage of immunostained cells in solid metastases compared to effusions $(p=0.036)$. Endoglin expression did not correlate with survival. Tumor cell endoglin expression is higher in post- vs. prechemotherapy effusions, whereas the opposite is seen in mesothelial cells. Together with its upregulation in solid metastases, this suggests that the expression and biological role of endoglin may differ between cell populations and change along tumor progression in ovarian carcinoma.

Keywords Endoglin - Ovarian carcinoma $\cdot$ Malignant effusions $\cdot$ Biomarker $\cdot$ Chemotherapy $\cdot$ Disease progression

\section{Introduction}

Ovarian carcinoma (OC) makes up $90 \%$ of all ovarian cancers [1] and is the leading cause of gynecological cancer death in Western countries [2]. Two thirds of OC patients present with metastases at diagnosis. The peritoneum, omentum, pelvis and abdominal viscera are common sites of seeding, and more than any other neoplasm, OC is associated with development of ascites [3]. The pleural cavity constitutes the most frequent location of extra-abdominal disease [4]. There 
is an ongoing search for highly sensitive and specific biomarkers to improve early diagnosis and thereby reduce morbidity and mortality of OC. New prognostic and predictive markers are needed to better assess patient outcome and guide individual therapies.

Endoglin (CD105) is a $180-\mathrm{kDa}$ homodimeric glycoprotein composed of two $95 \mathrm{kDa}$ disulfide-linked subunits. It has a transmembrane structure and functions as a component of the transforming growth factor- $\beta$ receptor complex. Endoglin is highly expressed on proliferating endothelial cells and is critical for angiogenesis. Endoglin-stimulated tumor angiogenesis is probably regulated via hypoxia, which is among the few known inducers of endoglin production $[5,6]$.

A soluble form of endoglin ( $\mathrm{sEng}$ ) is found in the circulation under normal and pathologic conditions. Breast and colorectal cancer patients exhibit higher sEng serum concentrations than healthy individuals, with the highest concentrations found in patients with metastatic disease [5]. sEng is increased in sera of pregnant women and is markedly elevated in preeclamptic patients. The serum sEng concentration increases prior to the onset of preeclampsia and correlates with disease severity $[7,8]$.

Endoglin immunoreactivity in endothelial cells has been used to determine intratumoral microvessel density (MVD) of solid neoplasms. High endoglin-determined MVD correlates with metastatic disease and low survival rates in a range of human malignancies, including breast, gastrointestinal, prostate, cervical, and head/neck cancer [9-15]. Taskiran et al. demonstrated endoglin expression, evaluated as MVD, to be an independent predictor of poor overall survival (OS) in OC [16]. However, Rubatt et al. postulated that high endoglinassessed MVD predicts increased risk of OC progression but not increased risk of disease-related death [17].

Malignant cells express endoglin in the cytoplasm, although staining is less frequent than in endothelial cells [5]. Henriksen et al. found endoglin expression in OC cells of primary tumors, but without significant difference from the expression seen in normal ovarian epithelium. High OC cell endoglin staining correlated with short OS [18]. We have recently found that high tumor cell endoglin expression in breast cancer effusions independently predicts poor disease-free survival and OS [19].

Similarly to the situation in breast cancer effusions, endoglin expression in OC effusions could be a marker of disease outcome. This theory is supported by the prognostic value of endoglin found in OC primary tumors [18] and by the presence of high sEng concentrations in plasma and effusions from OC patients [20]. In the present study, we analyzed endoglin expression in $\mathrm{OC}$ effusions and its association with clinicopathologic parameters, including survival, in a large cohort of patients with serous carcinoma. Endoglin expression in effusions was compared to that in primary tumors and solid metastatic lesions from the same patients. Effusion cells were considered a source of sEng, and cellular endoglin expression was therefore compared to the sEng concentration in corresponding effusions.

\section{Material and methods}

Patients and material

Biological material and clinical data were obtained during 1998-2005 from the Department of Gynecologic Oncology at the Norwegian Radium Hospital. Two hundred and eleven fresh, non-fixed peritoneal $(n=174)$ and pleural $(n=$ 37) effusions were obtained from 211 patients diagnosed with serous OC $(n=177)$, primary peritoneal serous carcinoma $(n=25)$ or tubal serous carcinoma $(n=9)$. Due to their closely linked histogenesis and phenotype, all these tumors are referred to as OC in the following sections. The majority of patients $(192 / 211$; 91\%) received platinumbased chemotherapy at diagnosis. One hundred and twentyseven effusions were obtained at diagnosis, prior to the administration of chemotherapy and will be referred to as prechemotherapy specimens, whereas 84 effusions were obtained after chemotherapy, henceforth referred to as postchemotherapy specimens. Clinicopathologic data are detailed in Table 1.

Peritoneal and pleural effusions were submitted for routine diagnostic purposes to the Division of Pathology and processed immediately after tapping. Effusion cell blocks were prepared using the thrombin clot method [21]. Effusion supernatants were fresh-frozen at $-70^{\circ} \mathrm{C}$. Diagnoses were established by morphology and immunohistochemistry [22].

Matched solid tumors were available from 34 patients and were included for comparative purposes. These consisted of 34 primary tumors and 34 solid intraperitoneal metastases, the majority of which were omental.

The study was approved by the Regional Committee for Medical and Health Research Ethics in South-Eastern Norway.

Immunohistochemistry

Cellular endoglin expression was analyzed by immunohistochemistry performed on formalin-fixed, paraffinembedded sections of OC effusions and solid tumors. All steps were performed at room temperature. Slides were pretreated using PT Link in combination with a Target Retrieval Solution (50× Tris/EDTA buffer, $\mathrm{pH}$ 9), both from Dako (Glostrup, Denmark). Following blocking of endogenous peroxidase activity and washing, a mouse monoclonal anti-endoglin antibody (Novocastra/Leica, Newcastle Upon Tyne, UK) in a 1:200 dilution was applied. The slides were incubated for $30 \mathrm{~min}$. Visualization was achieved using the EnVision ${ }^{\mathrm{TM}}$ FLEX+System (Dako). Sections of OC tissue 
Table 1 Clinicopathologic data of the study cohort (211 patients)

\begin{tabular}{|c|c|c|c|}
\hline \multicolumn{2}{|l|}{ Parameter } & \multirow{2}{*}{$\begin{array}{l}\begin{array}{l}\text { Primary } \\
\text { diagnosis }(=127)\end{array} \\
\begin{array}{l}39-87 \\
(\text { mean }=63)\end{array}\end{array}$} & \multirow{2}{*}{$\begin{array}{l}\begin{array}{l}\text { Disease } \\
\text { recurrence }(=84)\end{array} \\
\begin{array}{l}34-88 \\
(\text { mean }=59)\end{array}\end{array}$} \\
\hline Age & $\begin{array}{l}\text { Mean; } \\
\text { range }\end{array}$ & & \\
\hline \multirow[t]{4}{*}{ FIGO stage } & I & 1 & 0 \\
\hline & II & 0 & 1 \\
\hline & III & 69 & 62 \\
\hline & IV & 57 & 21 \\
\hline \multirow[t]{4}{*}{ Grade } & I & 10 & 5 \\
\hline & II & 32 & 17 \\
\hline & III & 69 & 59 \\
\hline & $\mathrm{NA}^{\mathrm{a}}$ & 16 & 3 \\
\hline \multirow[t]{3}{*}{ Residual disease } & $\leq 1 \mathrm{~cm}$ & 51 & 31 \\
\hline & $>1 \mathrm{~cm}$ & 54 & 43 \\
\hline & $\mathrm{NA}^{\mathrm{b}}$ & 22 & 10 \\
\hline \multirow{3}{*}{$\begin{array}{l}\text { Chemoresponse } \\
\text { at diagnosis }\end{array}$} & Complete & 70 & 49 \\
\hline & Incomplete $^{c}$ & 48 & 33 \\
\hline & $\mathrm{ND}^{\mathrm{d}}$ & 9 & 2 \\
\hline \multirow{3}{*}{$\begin{array}{l}\text { Chemoresponse } \\
\text { at first relapse }\end{array}$} & Complete & 13 & 20 \\
\hline & Incomplete $^{c}$ & 79 & 57 \\
\hline & $\mathrm{ND}^{\mathrm{d}}$ & 35 & 7 \\
\hline
\end{tabular}

${ }^{\mathrm{a}} \mathrm{NA}=$ not available; including effusions from inoperable patients where biopsy was too small for grading $(n=9)$ and patients operated in other hospitals, for which the primary tumor could not be accessed for assessment of grade $(n=10)$

${ }^{\mathrm{b}}$ Nine patients who were inoperable and 23 patients with no record

${ }^{\mathrm{c}}$ Partial response/stable disease/progression/allergic or adverse reaction

${ }^{\mathrm{d}} \mathrm{ND}=$ non-determined, including patients who received no chemotherapy and patients who died before chemoresponse could be assessed

previously shown to express endoglin were used as positive controls. In negative controls, the primary anti-endoglin antibody was replaced by a non-relevant antibody of the same isotype (mouse IgG2a). Specimens containing less than 100 tumor cells were excluded from the study. Staining localized to the cell membrane or cytoplasm was considered positive. Semi-quantitative scoring of staining was performed using a $0-4$ scale, corresponding to $0 \%, 1-5 \%, 6-$ $25 \%, 26-75 \%$, and $76-100 \%$ staining of cancer cells, respectively. Mesothelial cell endoglin expression was considered either positive or negative and was not further categorized. The slides were scored by three authors $(\mathrm{AB}$, $\mathrm{AaB}$, and $\mathrm{BD}$ ), of whom the two last-named are experienced cytopathologists.

\section{Statistical analysis}

Statistical analysis was performed using SPSS (Statistical Program of Social Sciences, version 16.0, Chicago, IL). A probability $<0.05$ was considered significant. Analyses of the associations between endoglin expression and clinicopathologic parameters were undertaken using the MannWhitney test. Clinicopathologic parameters were categorized as follows: age, $\leq 60$ vs. $>60$ years; histological grade (FIGO system), 1-2 vs. 3; effusion site, peritoneal vs. pleural; FIGO stage, III vs. IV; residual tumor volume after surgery, $\leq 1$ vs. $>1 \mathrm{~cm}$; chemotherapy status, pre- vs. postchemotherapy specimens; response to chemotherapy for primary disease and for disease recurrence, complete vs. partial response/stable disease/progression/allergic or adverse reaction. Chemoresponse was assessed based on standard WHO criteria [23]. Endoglin expression in effusions, primary tumors and solid metastases was compared using the Wilcoxon signed-rank test.

Progression-free survival (PFS) and OS was calculated from the date of diagnosis to the date of disease recurrence/ death or last follow-up. Univariate survival analyses of PFS and OS were executed using the Kaplan-Meier method and $\log$-rank test. For this analysis, expression was grouped as low (score $0-2 ; 0-25 \%$ of cells) vs. high (score 3-4; 26-100\%) in order to include a sufficient number of cases in each category.

\section{Results}

Tumor and mesothelial cells in effusions express endoglin

Endoglin immunoreactivity was detected in OC cells in 95/ $211(45 \%)$ effusions. Staining score was as follows: 0, 116 (55\%) specimens; 1,50 specimens (24\%); 2, 23 specimens (11\%); 3, 18 (8\%) specimens; 4, 4 (2\%) specimens. Expression in mesothelial cells was seen in 133/211 (63\%) effusions (Fig. 1). In both cell types, endoglin staining was most frequently localized to the cytoplasm. Membrane expression was heterogeneous with both positive and negative cells seen in the same specimen.

Inter-observer agreement was good (70-80\%), with differences of one scoring level in the majority of discrepant cases. These were easily settled in consensus sessions.

Endoglin expression in effusions and clinicopathologic parameters

OC cell endoglin expression was comparable between peritoneal and pleural effusions, and this was also the case for expression in mesothelial cells (data not shown, $p>$ 0.05 ). A borderline significant finding indicated that patients aged $\leq 60$ years had higher tumor cell endoglin expression in effusions compared to older patients ( $p=$ $0.048)$. There was no association between mesothelial cell endoglin expression and age $(p>0.05)$. Tumor cell endoglin expression was significantly higher in post- vs. prechemotherapy effusions $(p=0.014)$. The inverse association was 
Fig. 1 Endoglin expression in ovarian carcinoma by immunohistochemistry. a Cytoplasmic expression in tumor cells in effusion; $\mathbf{b}$ membrane expression in reactive mesothelial cells in effusion (center). Cytoplasmic expression is seen in tumor cells; c membrane expression in carcinoma cells in effusion; $\mathbf{d}$ tumor cell cytoplasmic immunostaining in primary carcinoma; and e solid metastasis in the omentum. Endothelial cells are strongly immunoreactive; $\mathbf{f}$ stromal and endothelial endoglin expression in a primary ovarian carcinoma. Tumor cells are additionally

stained
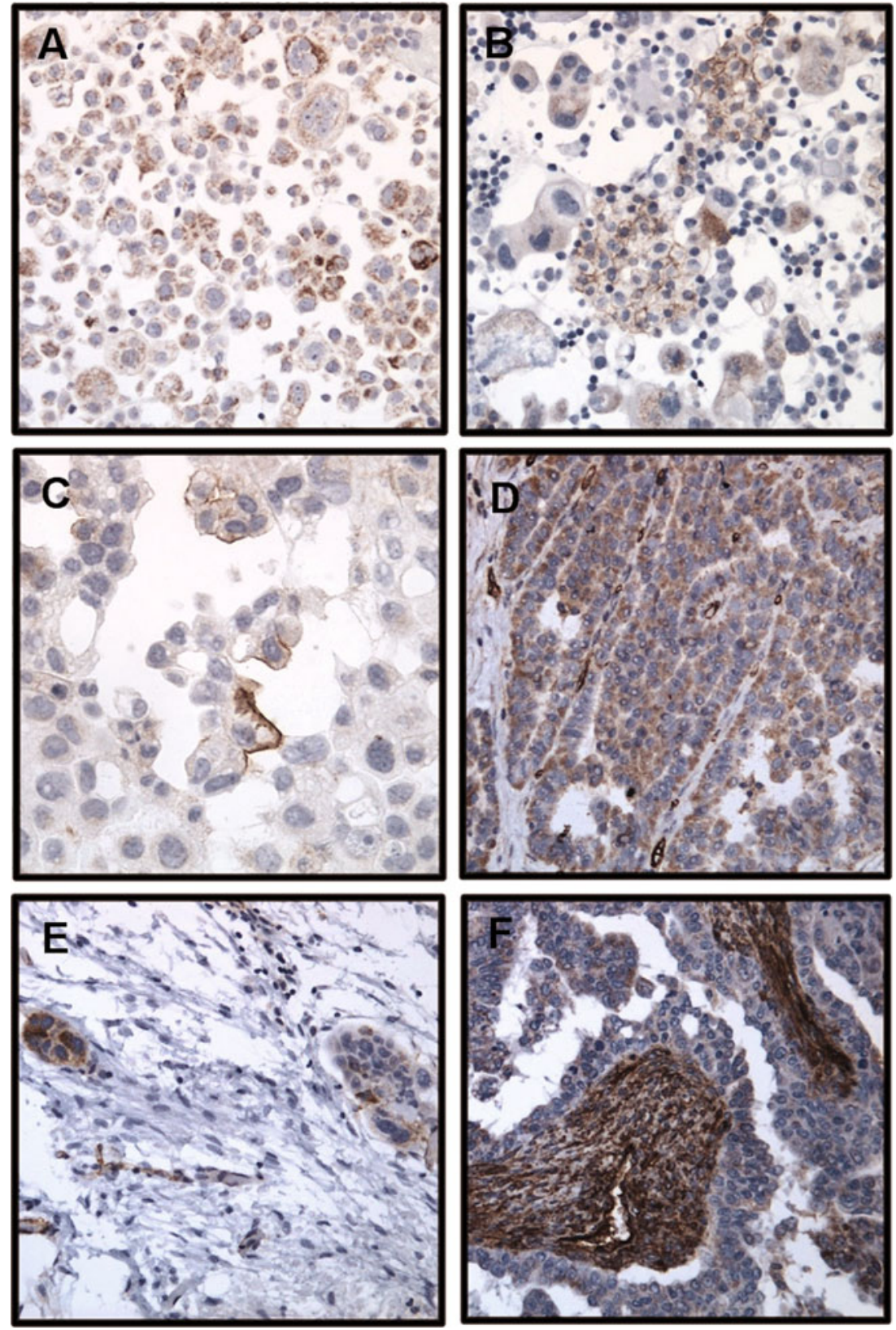

seen for mesothelial cells, with higher endoglin expression in pre- compared to postchemotherapy specimens ( $p=$ $0.021)$. Separate analysis with respect to treatment with a platinum agent (data available for 210/211 patients) showed a trend for higher tumor cell endoglin expression in effusions obtained after platinum treatment compared to effusions obtained at diagnosis, prior to treatment $(p=0.062)$, while mesothelial cells showed significantly higher staining in effusions obtained prior to treatment with a platinum compound $(p=0.019)$. Endoglin expression in tumor cells was marginally higher in effusions from patients treated with taxane, compared to the expression in effusions obtained prior to taxane therapy $(p=0.05)$. The expression in mesothelial cells was comparable regardless if the patient had received taxane or not $(p>0.05)$. Neither tumor nor mesothelial cell endoglin expression was associated with response to chemotherapy at diagnosis or at first disease recurrence. Irrespectively of cell type analyzed, endoglin expression was unrelated to tumor grade, FIGO stage, or residual disease volume after surgery $(p>0.05)$. The association between tumor and mesothelial endoglin expression and clinicopathologic data is detailed in Tables 2 and 3.

Solid tumors and endoglin

OC cells expressed endoglin in 17/34 (50\%) primary tumors, with a $0-4$ score in $17(50 \%), 10(29 \%), 6(18 \%)$, $1(3 \%)$, and 0 specimens, respectively. Tumor cell expres- 
Table 2 The association between tumor cell endoglin expression in effusions and clinicopathologic data (211 patients)
Clinical parameter

Staining extent (percentage of tumor cells) $p$ value

$\begin{array}{lllll}0 \% & 1-5 \% & 6-25 \% & 26-75 \% & 76-100 \%\end{array}$

\begin{tabular}{|c|c|c|c|c|c|c|c|}
\hline Site & $\begin{array}{l}\text { Peritoneum (174) } \\
\text { Pleura (37) }\end{array}$ & $\begin{array}{l}96 \\
20\end{array}$ & $\begin{array}{r}41 \\
9\end{array}$ & $\begin{array}{r}19 \\
4\end{array}$ & $\begin{array}{r}14 \\
4\end{array}$ & $\begin{array}{l}4 \\
0\end{array}$ & 0.928 \\
\hline Age & $\begin{array}{l}\leq 60(105) \\
>60(106)\end{array}$ & $\begin{array}{l}51 \\
65\end{array}$ & $\begin{array}{l}29 \\
21\end{array}$ & $\begin{array}{r}9 \\
14\end{array}$ & $\begin{array}{r}13 \\
5\end{array}$ & $\begin{array}{l}3 \\
1\end{array}$ & 0.048 \\
\hline Grade $^{\mathrm{a}}$ & $\begin{array}{l}1-2(64) \\
3(128)\end{array}$ & $\begin{array}{l}39 \\
65\end{array}$ & $\begin{array}{l}13 \\
30\end{array}$ & $\begin{array}{r}6 \\
17\end{array}$ & $\begin{array}{r}6 \\
12\end{array}$ & $\begin{array}{l}0 \\
4\end{array}$ & 0.164 \\
\hline FIGO stage ${ }^{b}$ & $\begin{array}{l}\text { III (131) } \\
\text { IV (78) }\end{array}$ & $\begin{array}{l}74 \\
42\end{array}$ & $\begin{array}{l}29 \\
20\end{array}$ & $\begin{array}{r}14 \\
9\end{array}$ & $\begin{array}{r}11 \\
6\end{array}$ & $\begin{array}{l}3 \\
1\end{array}$ & 0.855 \\
\hline Residual disease $^{c}$ & $\begin{array}{l}\leq 1 \mathrm{~cm} \mathrm{(82)} \\
>1 \mathrm{~cm} \mathrm{(97)}\end{array}$ & $\begin{array}{l}50 \\
46\end{array}$ & $\begin{array}{l}14 \\
29\end{array}$ & $\begin{array}{r}7 \\
12\end{array}$ & $\begin{array}{l}9 \\
9\end{array}$ & $\begin{array}{l}2 \\
1\end{array}$ & 0.208 \\
\hline Previous chemotherapy & $\begin{array}{l}\text { No }(127) \\
\text { Yes }(84)\end{array}$ & $\begin{array}{l}78 \\
38\end{array}$ & $\begin{array}{l}27 \\
23\end{array}$ & $\begin{array}{l}13 \\
10\end{array}$ & $\begin{array}{r}8 \\
10\end{array}$ & $\begin{array}{l}1 \\
3\end{array}$ & 0.014 \\
\hline Chemoresponse at diagnosis ${ }^{\mathrm{d}}$ & $\begin{array}{l}\text { Complete }(119) \\
\text { Other }(81)^{\mathrm{e}}\end{array}$ & $\begin{array}{l}67 \\
44\end{array}$ & $\begin{array}{l}26 \\
21\end{array}$ & $\begin{array}{l}10 \\
11\end{array}$ & $\begin{array}{r}13 \\
4\end{array}$ & $\begin{array}{l}3 \\
1\end{array}$ & 0.93 \\
\hline Chemoresponse at first recurrence ${ }^{f}$ & $\begin{array}{l}\text { Complete (33) } \\
\text { Other (136) }\end{array}$ & $\begin{array}{l}15 \\
77\end{array}$ & $\begin{array}{r}8 \\
33\end{array}$ & $\begin{array}{r}3 \\
13\end{array}$ & $\begin{array}{r}5 \\
12\end{array}$ & $\begin{array}{l}2 \\
1\end{array}$ & 0.129 \\
\hline
\end{tabular}

sion was seen in 19/34 (55\%) solid metastases. The $0-4$ score distribution for metastases was as follows: $15(45 \%)$, $9(26 \%), 9(26 \%), 1(3 \%)$, and 0 (Fig. 1). Equivalent to the finding in effusions, endoglin expression in solid tumors was mainly localized to the cytoplasm, although membranous staining was seen in many of the positive tumors. Endoglin expression in solid metastases was higher than in effusions $(p=0.036)$. Similarly, a non-significant trend indicated higher expression in primary tumors compared to effusions ( $p=$ $0.122)$. No difference in endoglin staining was seen between solid metastases and primary tumors $(p>0.05)$. Endoglin immunoreactivity was additionally seen in endothelial cells in blood vessels and in the stroma of solid tumors, the former serving as an internal positive control (Fig. 1).

The concentration of soluble endoglin in effusions is unrelated to cellular protein expression

Cellular endoglin expression was analyzed for association with the concentration of sEng previously measured in 164 effusions [20], of which 95 were immunostained in the present study. The sEng concentration was independent of immunohistochemical endoglin staining in tumor and mesothelial cells (data not shown, $p>0.05$ ).
Table 3 The association between mesothelial cell endoglin expression in effusions and clinicopathologic data (211 patients)

\footnotetext{
${ }^{\mathrm{a}}$ Nineteen non-graded tumors

${ }^{\mathrm{b}}$ Two stage I-II patients

${ }^{\mathrm{c}}$ Thirty-two patients with no data

${ }^{\mathrm{d}}$ Eleven patients with no data

${ }^{\mathrm{e}}$ Partial response/stable disease/ progression/allergic or adverse reaction

${ }^{\mathrm{f}}$ Forty-two patients with no data
}

\begin{tabular}{|c|c|c|c|c|}
\hline \multirow[t]{2}{*}{ Clinical parameter } & & \multicolumn{2}{|c|}{ Staining } & \multirow[t]{2}{*}{$p$ value } \\
\hline & & No & Yes & \\
\hline Site & $\begin{array}{l}\text { Peritoneum (174) } \\
\text { Pleura (37) }\end{array}$ & $\begin{array}{l}62 \\
16\end{array}$ & $\begin{array}{r}112 \\
21\end{array}$ & 0.385 \\
\hline Age & $\begin{array}{l}\leq 60(105) \\
>60(106)\end{array}$ & $\begin{array}{l}41 \\
37\end{array}$ & $\begin{array}{l}64 \\
69\end{array}$ & 0.594 \\
\hline Grade $^{\mathrm{a}}$ & $\begin{array}{l}1-2(64) \\
3(128)\end{array}$ & $\begin{array}{l}20 \\
51\end{array}$ & $\begin{array}{l}44 \\
77\end{array}$ & 0.246 \\
\hline FIGO stage ${ }^{b}$ & $\begin{array}{l}\text { III (131) } \\
\text { IV (78) }\end{array}$ & $\begin{array}{l}53 \\
25\end{array}$ & $\begin{array}{l}78 \\
53\end{array}$ & 0.225 \\
\hline Residual disease ${ }^{c}$ & $\begin{array}{l}\leq 1 \mathrm{~cm} \mathrm{(82)} \\
>1 \mathrm{~cm} \mathrm{(97)}\end{array}$ & $\begin{array}{l}33 \\
34\end{array}$ & $\begin{array}{l}49 \\
63\end{array}$ & 0.476 \\
\hline Previous Chemotherapy & $\begin{array}{l}\text { No }(127) \\
\text { Yes }(84)\end{array}$ & $\begin{array}{l}39 \\
39\end{array}$ & $\begin{array}{l}88 \\
45\end{array}$ & 0.021 \\
\hline Chemoresponse at diagnosis $^{\mathrm{d}}$ & $\begin{array}{l}\text { Complete (119) } \\
\text { Other }(81)^{\mathrm{e}}\end{array}$ & $\begin{array}{l}43 \\
31\end{array}$ & $\begin{array}{l}76 \\
50\end{array}$ & 0.759 \\
\hline Chemoresponse at first recurrence ${ }^{f}$ & $\begin{array}{l}\text { Complete (33) } \\
\text { Other }(136)^{\mathrm{e}}\end{array}$ & $\begin{array}{l}15 \\
45\end{array}$ & $\begin{array}{l}18 \\
91\end{array}$ & 0.184 \\
\hline
\end{tabular}


Endoglin expression does not correlate with survival

The role of endoglin in predicting survival was assessed. Follow-up ranged from $1-110$ months (mean $=31$ months, median $=26$ months). PFS ranged from 0-66 months (mean $=8$ months, median $=5$ months). At the last followup, four patients were alive without disease, 16 were alive with disease, and 190 were dead of disease. One patient died of an unrelated cause. No association was seen between endoglin expression in effusion OC cells or in mesothelial cells and OS or PFS $(p>0.05)$. Patients with pre- and postchemotherapy effusions were additionally analyzed separately, as previous studies have shown that the expression and clinical relevance of cancer-associated molecules differ between primary diagnosis and disease recurrence effusions [24]. As in the analysis of the entire cohort, tumor or mesothelial cell endoglin expression did not correlate with OS or PFS in these groups $(p>0.05)$.

\section{Discussion}

Women diagnosed with advanced-stage $\mathrm{OC}$ have poor prognosis. They may benefit from molecular targeted therapies, but extended knowledge about OC biology is needed to make such treatment possible. We have previously documented the differential expression of cancer-associated genes in effusions, primary tumors, and solid metastatic lesions from OC patients. A prognostic value of several of these molecules has also been reported $[3,25]$. To study the significance of endoglin expression in OC, we included a large dataset of 211 malignant effusions with 34 corresponding primary tumors and solid metastatic lesions. Most previous studies exploring a role of endoglin in cancer have focused on its expression in endothelial cells. In the present study, endoglin staining was found by immunohistochemistry in both OC and mesothelial cells in effusions. Chemotherapy status was significantly associated with the extent of endoglin expression in effusions.

The tumor microenvironment plays a crucial role in modifying the cancer cell phenotype [26]. We therefore compared endoglin expression in OC effusions, primary tumors, and solid metastases, and found significantly higher expression in solid metastases vs. effusions. As described above, endoglin stimulates angiogenesis, which is necessary for oxygen and nutrient supply when the tumor diameter expands beyond the diffusion limits of 1-2 mm [27]. In effusions, nutrient and oxygen supply to the freefloating OC cells could occur by diffusion of soluble molecules in the fluidic microenvironment. This may explain why endoglin expression was higher in the compact solid tumors, which are totally dependent upon angiogenesis for their nutrient and oxygen supply. Opposing the findings of the present study, however, we recently found significantly higher endoglin expression frequency in breast carcinoma effusions compared to primary tumors, suggesting that the variation in endoglin expression along tumor progression may be tumor type-specific [19].

OC cell endoglin expression was higher in post- vs. prechemotherapy effusions. Separate analyses of previous platinum- or taxane-based chemotherapy both revealed higher OC cell endoglin expression in effusions obtained after treatment. The administration of cytotoxic drugs thus seems to influence endoglin expression. On the other hand, diverging expression in pre-and postchemotherapy specimens could reflect biological changes occurring during the process of $\mathrm{OC}$ progression. This theory is supported by previous findings of increasing endoglin expression in the epithelial and stromal compartments of the normal prostate with the development of prostate intraepithelial neoplasia and carcinoma [28]. In vitro, endoglin suppresses cell adhesion, motility, and invasion of prostate cancer cells, and loss of endoglin expression appears to be associated with prostate cancer progression [29, 30]. Thus, endoglin may play a dual role in carcinogenesis, and the setting in which endoglin is expressed is probably important for its biological function. In contrast to the situation in tumor cells, mesothelial cell endoglin expression was higher in pre- compared to postchemotherapy specimens, which could be explained by differences in protein function and requirements of the two cell types.

We hypothesized sEng to be at least in part locally produced by effusion cells. Similarly to sEng in the circulation [31], sEng in effusions might be released by proteolytic cleavage of membrane-bound protein. Our study revealed frequent endoglin expression in $\mathrm{OC}$ and mesothelial cells, although cellular staining was unrelated to sEng effusion concentrations. In addition to leakage of plasma sEng into the serosal cavities, local endoglin production by tumor and mesothelial cells may increase sEng effusion concentration.

It has been discussed whether OC cells are shed into the peritoneal cavity from the primary ovarian tumor and whether they are of a truly metastatic nature. Protein expression patterns of tumor cells in peritoneal effusions seem to resemble those in pleural effusions, which are beyond all doubt metastatic [3]. The present study revealed comparable endoglin expression in effusions from both anatomic sites, further indicating a common biology for peritoneal and pleural $\mathrm{OC}$ effusions and a metastatic nature also of the former.

High endoglin expression in primary tumors has previously been related to poor survival in OC patients [18]. However, cellular endoglin expression in OC effusions did not correlate with disease outcome. This is in agreement with results of our previous study, in which we reported that the concentration of sEng in OC effusions was unrelated to survival [20]. In 
contrast, high tumor cell endoglin expression in breast cancer effusions was found to be an independent prognostic marker of poor disease-free and overall survival [19]. The value of endoglin as a prognostic marker in breast cancer effusions, but not in OC effusions, may reflect differences in tumor biology between these two epithelial malignancies.

In conclusion, endoglin is frequently expressed in OC effusions, both in tumor and reactive mesothelial cells. The extent of endoglin expression is related to chemotherapy status and is higher in solid metastatic tumors compared to effusions, indicating that protein expression is regulated according to cellular requirements in the setting of OC progression. Expression in reactive mesothelial cells is well in agreement with the ability of these cells to produce angiogenic factors. Novel antiangiogenic therapeutic approaches targeting endoglin have been developed, and initial preclinical studies demonstrate clinical value for monoclonal antibodies targeting angiogenic factors in cancer therapy [31]. Even though we found that endoglin expression in OC effusions was unrelated to survival, our study does not rule out such a therapeutic approach in OC. This may be an especially attractive approach in view of the expression of endoglin in endothelial cells, the tumor stroma, and carcinoma cells.

Financial acknowledgements This study was supported by a grant from the Norwegian Cancer Society, by the Research Foundation of the Norwegian Radium Hospital, and by the Inger and John Fredriksen Foundation for Ovarian Cancer Research.

Annika J. Bock is the receiver of a $\mathrm{MD} / \mathrm{PhD}$ student scholarship from the Faculty of Medicine, University of Oslo.

Open Access This article is distributed under the terms of the Creative Commons Attribution Noncommercial License which permits any noncommercial use, distribution, and reproduction in any medium, provided the original author(s) and source are credited.

\section{References}

1. Robboy SJ. Robboy's pathology of the female reproductive tract. 2nd ed. Edinburgh: Churchill Livingstone Elsevier; 2009. p. 611.

2. Jemal A, Siegel R, Ward E, Hao Y, Xu J, Thun MJ. Cancer statistics, 2009. CA Cancer J Clin. 2009;59:225-49.

3. Davidson B, Risberg B, Reich R, Berner A. Effusion cytology in ovarian cancer: new molecular methods as aids to diagnosis and prognosis. Clin Lab Med. 2003;23:729-54.

4. Cannistra SA. Cancer of the ovary. N Engl J Med. 2004;351:2519-29.

5. Fonsatti E, Altomonte M, Nicotra MR, Natali PG, Maio M. Endoglin (CD105): a powerful therapeutic target on tumor-associated angiogenetic blood vessels. Oncogene. 2003;22:6557-63.

6. Dallas NA, Samuel S, Xia L, Fan F, Gray MJ, Lim SJ, et al. Endoglin (CD105): a marker of tumor vasculature and potential target for therapy. Clin Cancer Res. 2008;14:1931-7.

7. Levine RJ, Lam C, Qian C, Yu KF, Maynard SE, Sachs BP, et al. Soluble endoglin and other circulating antiangiogenic factors in preeclampsia. N Engl J Med. 2006;355:992-1005.

8. Staff AC, Braekke K, Johnsen GM, Karumanchi SA, Harsem NK. Circulating concentrations of soluble endoglin (CD105) in fetal and maternal serum and in amniotic fluid in preeclampsia. Am J Obstet Gynecol. 2007;197:176.e1-6.

9. Kumar S, Ghellal A, Li C, Byrne G, Haboubi N, Wang JM, et al. Breast carcinoma: vascular density determined using CD105 antibody correlates with tumor prognosis. Cancer Res. 1999;59:856-61.

10. Saad RS, Liu YL, Nathan G, Celebrezze J, Medich D, Silverman JF. Endoglin (CD105) and vascular endothelial growth factor as prognostic markers in colorectal cancer. Mod Pathol. 2004; 17:197-203.

11. Saad RS, El-Gohary Y, Memari E, Liu YL, Silverman JF. Endoglin (CD105) and vascular endothelial growth factor as prognostic markers in esophageal adenocarcinoma. Hum Pathol. 2005;36:955-61.

12. Ding S, Li C, Lin S, Yang Y, Liu D, Han Y, et al. Comparative evaluation of microvessel density determined by CD34 or CD105 in benign and malignant gastric lesions. Hum Pathol. 2006;37:861-6.

13. Chien C, Su C, Hwang C, Chuang H, Chen C, Huang C. High expressions of CD105 and VEGF in early oral cancer predict potential cervical metastasis. J Surg Oncol. 2006;94:413-7.

14. El-Gohary YM, Silverman JF, Olson PR, Liu YL, Cohen JK, Miller R, et al. Endoglin (CD105) and vascular endothelial growth factor as prognostic markers in prostatic adenocarcinoma. Am J Clin Pathol. 2007;127:572-9.

15. Zijlmans HJ, Fleuren GJ, Hazelbag S, Sier CF, Dreef EJ, Kenter $\mathrm{GG}$, et al. Expression of endoglin (CD105) in cervical cancer. Br J Cancer. 2009;100:1617-26.

16. Taskiran C, Erdem O, Onan A, Arisoy O, Acar A, Vural C, et al. The prognostic value of endoglin (CD105) expression in ovarian carcinoma. Int J Gynecol Cancer. 2006;16:1789-93.

17. Rubatt JM, Darcy KM, Hutson A, Bean SM, Havrilesky LJ, Grace LA, et al. Independent prognostic relevance of microvessel density in advanced epithelial ovarian cancer and associations between CD31, CD105, p53 status, and angiogenic marker expression: a gynecologic oncology group study. Gynecol Oncol. 2009;112:469-74.

18. Henriksen R, Gobl A, Wilander E, Oberg K, Miyazono K, Funa $\mathrm{K}$. Expression and prognostic significance of TGF-beta isotypes, latent TGF-beta 1 binding protein, TGF-beta type I and type II receptors, and endoglin in normal ovary and ovarian neoplasms. Lab Invest. 1995;73:213-20.

19. Davidson B, Stavnes HT, Førsund M, Berner A, Staff AC. CD105 (Endoglin) expression in breast carcinoma effusions is a marker of poor survival. Breast. 2010;19:493-8.

20. Ødegaard E, Davidson B, Engh V, Onsrud M, Staff AC. Assessment of endoglin and calprotectin as potential biomarkers in ovarian carcinoma and borderline tumors of the ovary. Am J Obstet Gynecol. 2008;199:533.e1-8.

21. Bibbo M. Comprehensive cytopathology. 1st ed. Philadelphia: Saunders; 1991. p. 543.

22. Davidson B, Nielsen S, Christensen J, Asschenfeldt P, Berner $\mathrm{A}$, Risberg B, et al. The role of desmin and $\mathrm{N}$-cadherin in effusion cytology: a comparative study using established markers of mesothelial and epithelial cells. Am J Surg Pathol. 2001;25:1405-12.

23. Miller AB, Hoogstraten B, Staquet M, Winkler A. Reporting results of cancer treatment. Cancer. 1981;47:207-14.

24. Davidson B. Biological characteristics of cancers involving the serosal cavities. Crit Rev Oncog. 2007;13:189-227.

25. Davidson B. Malignant effusions: from diagnosis to biology. Diagn Cytopathol. 2004;31:246-54.

26. Liotta LA, Kohn EC. The microenvironment of the tumour-host interface. Nature. 2001;411:375-9.

27. Zetter BR. The scientific contributions of M. Judah Folkman to cancer research. Nat Rev Cancer. 2008;8:647-54. 
28. Kassouf W, Ismail HR, Aprikian AG, Chevalier S. Wholemount prostate sections reveal differential endoglin expression in stromal, epithelial, and endothelial cells with the development of prostate cancer. Prostate Cancer Prostatic Dis. 2004; 7:105-10.

29. Liu Y, Jovanovic B, Pins M, Lee C, Bergan RC. Over expression of endoglin in human prostate cancer suppresses cell detachment, migration and invasion. Oncogene. 2002;21:827281.

30. Craft CS, Romero D, Vary CP, Bergan RC. Endoglin inhibits prostate cancer motility via activation of the ALK2-Smad1 pathway. Oncogene. 2007;26:7240-50.

31. ten Dijke P, Goumans M, Pardali E. Endoglin in angiogenesis and vascular diseases. Angiogenesis. 2008;11:79-89. 